\title{
IMPLEMENTASI SISTEM MANAJEMEN MUTU BERDASARKAN ISO 9001:2015 DI SEKOLAH DASAR KATOLIK SANTA CLARA SURABAYA
}

\author{
Muryadi \\ Soedjarwo \\ Mudjito \\ Universitas Negeri Surabaya \\ gittmuryadi@gmail.com
}

\begin{abstract}
Santa Clara Catholic Elementary School Surabaya has received an ISO 9001: 2015 certificate with number 234872, which came into force from May 31, 2017 until July 12, 2020. Previously, this school had implemented ISO 9001: 2008. So in the application of a quality management system based on ISO 9001: 2015 there are some fundamental changes that must be made by organizations that adopt it in order to obtain added value in their services. This study aims to describe the implementation of a quality management system based on ISO 9001: 2015 at Santa Clara Catholic Elementary School in Surabaya, especially the application of seven ISO 9001: 2015 quality management principles: customer focus, leadership, people involvement, process approach, improvement, evidence-based decision making and relationship management and inhibiting factors and supporting the implementation of the ISO 9001: 2015 quality management system at Santa Clara Catholic Elementary School in Surabaya. This research uses a descriptive qualitative approach. Data collection uses in-depth interview techniques, participant observation and documentation. While the data analysis technique uses descriptive analysis through three steps, namely: (1) data condensation, (2) data presentation, (3) drawing conclusions. Data validity techniques use: (1) credibility including: (a) prolonged engagement, (b) persistent observation, (c) triangulation, (d) peer debrieffing, (e) referential adequacy checks, (f) member checks. (2) dependability, (3) confirmability, (4) transferability. The results of this study indicate the Catholic School of Santa Clara Surabaya has applied the principle of customer focus in the implementation of the ISO 9001: 2015 Quality Management System.
\end{abstract}

Keywords: Implementation, ISO 9001: 2015 Quality Management System

\begin{abstract}
Abstrak: Sekolah Dasar Katolik Santa Clara Surabaya telah mendapatkan sertifikat ISO 9001:2015 dengan nomor 234872 yang mulai berlaku sejak 31 Mei 2017 sampai 12 Juli 2020. Sebelumnya Sekolah ini sudah menerapkan ISO 9001:2008. Maka dalam penerapan sistem manajemen mutu berdasarkan ISO 9001:2015 ada beberapa perubahan mendasar yang harus dilakukan organisasi yang mengadopsinya agar memperoleh nilai tambah dalam pelayanannya. Penelitian ini bertujuan mendeskripsikan implementasi system manajemen mutu berdasarkan ISO 9001:2015 di SD Katolik Santa Clara Surabaya terutama penerapan tujuh prinsip manajemen mutu ISO 9001:2015: fokus pelanggan, kepemimpinan, keterlibatan orang, pendekatan proses, peningkatan, pengambilan keputusan berbasi bukti dan manajemen hubungan serta faktor penghambat dan pendukung implementasi system manajemen mutu ISO 9001:2015 di SD Katolik Santa Clara Surabaya. Penelitian ini menggunakan pendekatan kualitatif deskriptif. Pengumpulan data menggunakan teknik wawancara mendalam, observasi partisipan dan dokumentasi. Sedangkan teknik analisis data menggunakan analisis deskriptif melalui tiga langkah yaitu: (1) kondensasi data, (2) penyajian data, (3) penarikan simpulan. Teknik keabsahan data menggunakan: (1) kredibilitas meliputi: (a) prolonged engagement, (b) persistant observation, (c) trianggulasi, (d) peer debrieffing, (e) referential adequancy checks, (f) member checks. (2) dependabilitas, (3) konfirmabilitas, (4) transferabilitas. Hasil penelitian ini menunjukkan SD Katolik Santa Clara Surabaya sudah menerapkan prinsip focus pelanggan dalam implement-tasi Sistem Manajemen Mutu ISO 9001:2015
\end{abstract}

Kata kunci: Implementasi, Sistem Manajemen Mutu ISO 9001:2015 
Dalam undang-undang no. 20 tahun 2003 tentang sistem pendidikan nasional dinyatakan pada pasal 3 bahwa, "tujuan pendidikan nasional adalah mengembangkan potensi peserta didik agar menjadi manusia yang beriman dan bertakwa kepada Tuhan Yang Maha Esa, berakhlak mulia, sehat, berilmu, cakap, kreatif, mandiri, dan menjadi warga negara yang demokratis serta bertanggung jawab". Jenjang pendidikan sekolah dasar merupakan fondasi bagi peletakan dasar kecerdasan, pengetahuan, kepribadian, akhlak mulia, serta keterampilan hidup mandiri dan mengikuti pendidikan lebih lanjut.

Untuk mencapai tujuan pendidikan tersebut Pemerintah Indonesia menetapkan anggaran pendidikan nasional yang besar mencapai $20 \%$. Hal ini tertuang dalam Undang-Undang Dasar 1945 hasil amandemen ke empat tahun 2002 pasal 31 ayat 4: Negara memprioritaskan anggaran pendidikan sekurang-kurangnya $20 \%$ dari anggaran pendapatan dan belanja negara serta dari anggaran pendapatan dan belanja daerah untuk memenuhi kebutuhan penyelenggaraan pendidikan nasional.

Tetapi harus diakui bahwa mutu pendidikan sekolah dasar dalam satu dekade terakhir ini belum menunjukkan hasil yang memuaskan. Berdasarkan data hasil Evaluasi Diri Sekolah (EDS) pada tahun 2013 yang diikuti 132.370 dari 148.107 atau $89,4 \%$ menunjukkan gambaran pemenuhan Standar Nasional Pendidikan (SNP) bahwa Sekolah Dasar (SD) masih banyak yang belum memenuhi SNP. Indakator lemahnya mutu pendidikan jenjang pendidikan dasar di Indonesia juga ditunjukkan dari hasil penelitian kemampuan membaca untuk tingkat Sekolah Dasar (SD) yang dilaksanakan oleh organisasi International Educational Achievement (IEA) menunjukkan bahwa siswa SD di Indonesia berada pada urutan ke-38 dari 39 negara peserta studi. Sedangkan untuk tingkat Sekolah Lanjutan Tingkat Pertama (SLTP), studi untuk kemampuan matematika siswa SLTP di Indonesia hanya berada pada urutan ke-39 dari 42 negara, dan untuk kemampuan IImu Pengetahuan Alam (IPA) hanya berada pada urutan ke-40 dari 42 negara
peserta.(Toha, 2006). Permasalahan ini ada pada komponen input pendidikan dan dapat dikategorikan sebagai masalah yang serius dan harus dipecahkan supaya proses pendidikan dapat mencapai mutu merata. (Cepi, 2015)

Permasalahan yang dihadapi bangsa Indonesia dalam hal pendidikan yaitu masih rendahnya mutu pendidikan di setiap jenjang. Departemen Pendidikan Nasional (2001:1) menjelaskan bahwa terdapat 3 faktor yang menyebabkan mutu pendidikan tidak mengalami peningkatan yaitu: (1) kebijakan dan penyelenggaraan pendidikan nasional menggunakan pendekatan education production function atau input analysis yang tidak dilaksanakan secara konsekuen. Dimana pendekatan ini kurang memperhatikan proses pendidikan. Padahal proses pendidikan menentukan output pendidikan; (2) penyelenggaraan pendidikan dilakukan secara birokratik-sentralistik dimana bergantung pada keputusan birokrasi sehingga sekolah tidak dapat mandiri dan tidak dapat mengembangkan dan memajukan lembaganya; dan (3) kurangnya peran serta dari masyarakat.

Untuk mewujudkan pendidikan yang bermutu maka diperlukan manajemen dan tata kelola yang baik. Menurut (Hanief, 2017) terdapat dua keuntungan bagi sekolah dengan adanya manajemen dan tata kelola yang baik. Pertama, sekolah dapat keluar dari struktur birokrasi yang ruwet. Kedua, sekolah lebih mandiri untuk menentukan dan mudah untuk mengatur dirinya sendiri.

Dengan melihat hal tersebut maka perlu adanya upaya perbaikan dan peningkatan mutu pendidikan yaitu dengan melakukan perbaikan secara berkelanjutan dalam hal proses pelaksanaan pendidikan, kemampuan Sumber Daya Manusia (SDM) dan lingkungan sekolah yaitu dengan menerapkan Sistem Manajemen Mutu (SMM) Berbasis ISO 9001:2015 yang merupakan revisi dari ISO 9001:2008. Penerapan SMM ISO 9001:2015 ini dilakukan agar manajemen sekolah bisa berjalan secara terencana dan sistematis sehingga dapat menghasilkan lulusan yang berkualitas dan tujuan pendidikan dapat tercapai secara efektif dan efisien. ISO (International Standards Organization) 
9001 merupakan standar yang mengatur tentang sistem manajemen mutu yang diakui internasional dan 2015 adalah menunjukkan hasil revisi tahun 2015.

Penyelenggaraan pendidikan di Kota Surabaya pada saat ini memang terus diupayakan untuk dapat menghasilkan mutu pendidikan yang bagus mulai dari tingkat dasar sampai perguruan tinggi. Kepala Dinas Pendidikan Kota Surabaya, Ikhsan, mengatakan "dengan upaya-upaya pembinaan dan peningkatan kualitas baik dari segi sumber daya manusia dan fasilitas pendidikan di Surabaya, Surabaya diharapkan dapat menjadi barometer pendidikan nasional di Indonesia". Usaha agar kota Surabaya menjadi barometer pendidikan nasional di Indonesia tidak akan terjadi dengan sendirinya. Hal itu menjadi tanggung jawab setiap satuan pendidikan dengan menempatkan sistem manajemen mutu sebagai bagian integral dari manajemen sistem, yang oleh Satori disebut Quality Assirance (Satori, 2016)

TQM di sekolah dasar merupakan usaha dasar yang sangat penting dilaksanakan untuk meraih kualitas pendidikan yang bagus. (Karakus, 2015). TQM merupakan sebuah konsep holistic untuk memotivasi orang orang yang berkaitan dengan system pendidikan sekolah dasar. (Hasan, Islam, Shams, \& Gupta, 2018)

Manajemen mutu adalah proses yang membutuhkan waktu yang lama, perubahan dapat diraih dengan kesabaran, kerjasama dan saling membantu.(Soheluz-zaman \& Anjalin, 2016)oleh karena itu, kerja tim adalah prinsip penting dalam implementasi TQM di sekolah untuk memprediksi prestasi akademik siswa. (Mukolwe, Michael, \& Jack, 2017)

Perbaikan berkelanjutan yang berfokus kepada mutu merupakan cara dasar untuk memenuhi persyaratan akuntabilitas dalam reformasi pendidikan.(Farooq, Akhtar, Ullah, \& Memon, 2007)

Kepala sekolah harus lebih aktif dan bijak dalam penerapan manajemen mutu disekolah. (Taahyadin \& Daud, 2018). Manajemen mutu di sekolah cenderung pasif tanpa partisipasi guru dalam mengontrol manajemen sekolah. (Yau, Lai, \& Cheng, 2013). Guru harus didorong aktif berpartisipasi untuk memberikan pendidikan yang berkualitas untuk meningkatkan manajemen mutu di sekolah. (Farkhondehzadeh et al., 2013)

Proses belajar mengajar yang secara khusus menekankan untuk mendapatkan hasil ujian yang terbaik. (Pourrajab, 2015). Perbaikan berkelanjutan kualitas pembelajaran untuk mendorong siswa berpikir kritis dan kreatif dalam menghadapi perubahan teknologi yang semakin pesat.(Crawford \& Shutler, 1999)

Sekolah Dasar Katolik Santa Clara merupakan salah satu Sekolah Dasar di Kota Surabaya. Sejak tahun 2010 menerapkan SMM ISO 9001:2008. Selama menerapkan sistem manajemen mutu ISO 9001:2008 sekolah ini tidak pernah kekurangan peserta didik. Kapasitas ruang kelas yang tersedia selalu penuh. Setiap tahun peserta didik kelas VI selalu lulus $100 \%$. Hasil survey kepuasaan orangtua peserta didik terhadap pelayan sekolah mengalami trend yang meningkat setiap tahunnya. Pada tahun 2019 akan merayakan 50 tahun melayani masyarakat. Dan mulai tahun 2017 menerapkan Sistem Manajemen Mutu ISO 9001:2015 diterapkan. Sepanjang peneliti ketahui, di antara Sekolah Dasar Katolik di Kota Surabaya, Sekolah Dasar Katolik Santa Clara adalah satu-satunya yang menerapkan sistem manajemen mutu berdasarkan ISO 9001:2015. Hasil audit eksternal pada bulan Juni 2017 Sekolah Dasar Katolik Santa Clara dinyatakan berhak mendapat sertifikat ISO 9001:2015. Dengan demikian dapat dikatakan bahwa ada semangat besar dari Sekolah Dasar Katolik Santa Clara Surabaya untuk berpartisipasi dalam menyelenggarakan pendidikan yang bermutu sekaligus mendukung harapan dinas pendidikan Kota Surabaya untuk menjadikan Surabaya sebagai barometer atau tolok ukur pendidikan nasional.

Namaun Sistem Manajemen Mutu ISO 9001:2015 yang diadaposi oleh sekolah datang dengan fokus yang benar-benar berbeda dari versi 9001:2008. Sistem Manajemen Mutu ISO 9001:2008 terlalu banyak persyaratan dokumen dan form. Semenatara itu ISO 9001:2015 tidak lagi terlalu mempersoalkan dokumen, melainkan fokus pada performa 
perusahaan dengan pendekatan pemikiran berbasis resiko (risk-basedthinking) dan konsep rencanakan-lakukan-periksaperbaiki (Plan-Do-Check-Action) yang diterapkan di seluruh level organisasi.

Perbedaan lain lagi bahwa Sistem Manajemen Mutu ISO 9001:2015, risiko dianggap sebagai suatu kesatuan yang tidak dipisahkan dari sistem. Dengan mengambil pendekatan yang berbasis risiko, organisasi diharapkan menjadi lebih proaktif ketimbang reaktif, senantiasa mencegah dan mengurangi efek yang tidak dikehendaki, dan selalu mempromo-sikan perbaikan sistem yang berkelanjutan/continoual improvement. Ketika manajemen risiko diterapkan, secara otomatis tindakan pencegahan akan dilakukan. ISO 9001:2015 mendefinisikan risiko sebagai dampak dari ketidakpastian pada hasil yang diharapkan, dengan pengertian: (1) dampak adalah penyimpangan dari yang diharapkanpositif maupun negatif; (2) resiko adalah tentang apa yang mungkin terjadi dan apa dampak yang mungkin terjadi; dan (3) risiko juga mempertimbangkan seberapa besar kemungkinannya untuk terjadi.

Proses untuk mengadopsi Sistem Manajemen Mutu ISO 9001 baik versi 2008 maupun 2015 di Sekolah Dasar Katolik Santa Clara Surabaya sebenarnya sama, mengadakan pelatihan bersama konsultan yang ditetapkan atau dipilih oleh yayasan, penyusunan persyaratan yang diminta oleh Sistem Manajemen Mutu ISO 9001, penerapan dan mengevaluasi atau mengaudit dan mendapatkan sertifikat. Pada persiapan mengadopsi Sistem Manajemen Mutu ISO 9001:2018 diadakan persiapan secara intensif. Konsultan yang dipilih yayasan juga mempersiapan tim yang mengikuti persiapan dengan kemampuan menjadi auditor internal. Dan sebelum dilaksanakan audit eksternal, konsultan pusat dari Jakarta turun langsung mengadakan pre-audit di Sekolah Dasar Katolik Santa Clara Surabaya. Sementara itu dalam mengadopsi Sistem Manajemen Mutu ISO 9001:2015 persiapan yang diadakan tidak maksimal. Hal itu pernah disampaikan oleh ibu Yayuk, wakil manajemen kepada peneliti: "aku juga masih bingung pak". Pernayatan senada juga pernah disampaikan oleh auditor eksternal saat penutupan audit sertifikasi. Pada waktu itu auditor memberikan komentar: "perlu memahami dengan lebih baik lagi persyaratan Sistem Manajemen Mutu ISO 9001:2015, para pemegang prosedur pemahaman tentang Sistem Manajemen Mutu ISO 9001:2015 masih mengambang".

Berdasarkan latar belakang dan keunikan dan masalah di atas peneliti tertarik untuk mengadakan penelitian tentang Implementasi Sistem Manajemen Mutu berdasarkan ISO 9001:2015 yang dilakukan oleh Sekolah Dasar Katolik Santa Clara Surabaya.

\section{METODE}

Penelitian ini bertujuan mendeskripsikan implementasi system manajemen mutu berdasarkan ISO 9001:2015 di SD Katolik Santa Clara Surabaya terutama penerapan tujuh prinsip manajemen mutu ISO 9001:2015: fokus pelanggan, kepemimpin-an, keterlibatan orang, pendekatan proses, peningkatan, pengambilan keputusan berbasi bukti dan manajemen hubungan serta faktor penghambat dan pendukung implementasi system manajemen mutu ISO 9001:2015 di SD Katolik Santa Clara Surabaya.

$\begin{array}{ccr}\text { Penelitian } & \text { ini } & \text { menggunakan } \\ \text { ndekatan } & \text { kualitatif } & \text { deskriptif. }\end{array}$ Pengumpulan data menggunakan teknik wawancara mendalam, observasi partisipan dan dokumentasi. Sedangkan teknik analisis data menggunakan analisis deskriptif melalui tiga langkah yaitu: (1) kondensasi data, (2) penyajian data, (3) penarikan simpulan. Teknik keabsahan data menggunakan: (1) kredibilitas meliputi: (a) prolonged engagement, (b) persistant observation, (c) trianggulasi, (d) peer debrieffing, (e) referential adequancy checks, (f) member checks. dependabilitas, (3) konfirmabilitas, (4) transferabilitas (Sugiyono, 2012)

\section{PEMBAHASAN}

\section{Implementasi Prinsip-prinsip Sistem Manajemen Mutu ISO 9001:2015}

1. Prinsip menajemen mutu pertama: Fokus Pelangan 
Dalam system manajemen ISO 9001:2015, yang menjadi fokus utama adalah untuk memenuhi persyaratan pelanggan dan berusaha melampaui harapan pelanggan.

Sekolah Dasar Katolik Santa Clara Surabaya merumuskan perencanaan strategis yang didahului dengan melakukan analisis pihak yang berkepentingan yang dituangkan dalam format interested parties dan di akhir tahun melakukan survey kepuasan pelanggan.Tujuan survey pelanggan adalah untuk mengetahui indeks kepuasan pelanggan (IKP) dan memperbaiki pelayanan. Hal tersebut sesuai dengan persyaratan ISO 9001: 2015 klausul 4.2 : memahami kebutuhan dan harapan dari pihak-pihak yang berkepen-tingan. Karena dampak atau potensi dampak pada kemampuan organisasi untuk secara konsisten menyediakan produk dan jasa yang memenuhi persyaratan pelanggan dan hukum serta peraturan yang berlaku, organisasi harus menetapkan: 1) Pihakpihak yang berkepentingan yang relevan dengan sistem manajemen mutu. 2) Persyaratan dari pihak-pihak yang berkepentingan yang relevan dengan sistem manajemen mutu. Organisasi harus memantau dan meninjau informasi tentang pihak-pihak yang berkepentingan dan persyaratan yang relevan dengan mereka.

Senada dengan beberapa pendapat di atas, (Ruslan, 2010) pelanggan, baik pelanggan internal maupun pelanggan eksternal merupakan driver. Pelanggan eksternal menentukan kualitas produk atau jasa yang disampaikan kepada mereka, sedangkan pelanggan internal berperan besar dalam menentukan kualitas manusia, proses, dan lingkungan yang berhubungan dengan produk atau jasa. Artinya pelanggan dalam sebuah organisasi mempunyai posisi yang sangat penting.

Persyaratan ISO 9001:2015 klausul 5.1.2 juga meminta seperti apa yang sudah dilakukan oleh SD Katolik Santa Clara yaitu "Fokus pelanggan, Manajemen puncak harus menunjukkan kepemimpinan dan komitmen terhadap fokus pelanggan dengan memastikan bahwa: 1) Pelanggan dan hukum yang berlaku dan persyaratan peraturan yang ditentukan, dipahami dan secara konsisten dipenuhi; 2) Risiko dan peluang yang dapat mempengaruhi kesesuaian terhadap produk dan pelayanan, dan, 3) Fokus pada peningkatan kepuasan pelanggan dipertahankan.

2. Prinsip manajemen mutu kedua : Kepemimpinan

Peran pemimpin dalam ISO 9001:2015 adalah menciptakan kesatuan tujuan dan arah dan keterlibatan orang mengaktifkan sebuah organisasi untuk menyelaraskan strategi, kebijakan, proses dan sumber daya untuk mencapai tujuan.

Kepala Sekolah SD Katolik Santa Clara, sebagai pimpinan puncak, dalam menjalankan perannya sebagai penanggungjawab utama, dibantu tim ISO (MR, DC dan para kepala bidang kerja) untuk menyusun Visi, Misi, kebijakan mutu, rencana strategis, FMEA dan sasaran mutu dan mensosialisasi-kannya. Hal ini sejalan dengan pendapat Tukiran (2016:29), pemimpin mempunyai dua tugas pokok yaitu: 1) menetapkan araah kebijakan organisasi dan, 2) menciptkan lingkungan kerja sehingga setiap komponen mampu berkontribusi secara maksimal untuk mencapai tujuan organisasi. Hal tersebut juga sesuai dengan persyaratan ISO 9001:2015 klausu 5.1.1 yang meminta organisasi yang mengadopsinya untuk menajalankan tugas kepemimpinan dengan komitmen yang tinggi. Manajemen puncak harus menunjukkan kepemimpinan dan komitmen terhadap sistem manajemen mutu dengan: 1) Mengambil tanggungjawab atas efektivitas sistem manajemen mutu, 2) Memastikan bahwa kebijakan mutu dan sasaran mutu ditetapkan dalam sistem manajemen mutu dan cocok dengan konteks dan arah strategis organisasi; 3) Memastikan integrasi persyaratan sistem manajemen mutu ke dalam proses-proses bisnis organisasi; 4) Mempromosikan penggunaan pendekatan proses dan pemikiran berbasis risiko; 5) Memastikan bahwa sumber daya yang dibutuhkan untuk sistem manajemen mutu tersedia; 6) Mengkomunikasikan pentingnya manajemen mutu yang efektif dan sesuai dengan persyaratan SMM; 6) Memastikan bahwa sistem manajemen 
mutu mencapai hasil yang telah diinginkan; dan 7) Melibatkan, mengarahkan dan mendukung orang-orang untuk berkontribusi terhadap efektivitas sistem manajemen mutu;

Prinsip manajemen mutu : kepeminpinan yang dijalankan oleh Sekolah Dasar Katolik Santa Clara Surabaya di atas pada dasarnya juga sesuai dengan model manajemen mutu pendidikan yang diterbitkan oleh Departemen Pendidikan Nasional (Depdiknas:2000), khusus-nya dalam model proses yang meliputi: 1) Efektifitas Proses belajar mengajar tinggi. 2) Kepemimpinan yang kuat. 3) Pengelolaan yang efektik tenaga kependidikan. 4) Sekolah memiliki budaya mutu. 5) Sekolah memiliki team work yang kompak, Cerdas, dan dinamis. 6) Sekolah memiliki kewenangan (kemandirian ). 7) Partisipasi warga sekolah dan masyarakat. 8) Sekolah memiliki keterbukaan (transparasi) manajemen. 9) Sekolah memiliki kemauan untuk berubah (Psikologis dan Fisik). 10) Sekolah melakukan evaluasi dan perbaikan secara berkelanjutan. 11) Sekolah responsif dan antisipatif terhadap kebutuhan. 12) Sekolah memiliki akuntabilitas. 13) Sekolah memiliki sustainbilitas. Karakteristik berkaitan dengan prinsip kepemimpinan di SD Katolik Santa Clara juga sejalan dengan pernyataan Rundle, 2015 yang mengatakan bahwa "Pentingnya setiap pemimpin menciptakan kesatuan tujuan, arah dan keterlibatan pegawai adalah untuk menyelaraskan strategi, kebijakan, proses, dan sumber daya dengan tujuan organisasi. Lebih spesifik, beberapa hal yang harus diperhatikan dalam mengimplemen-tasikan manajemen mutu yang berkaitan dengan prinsip kepemimpinan, diantaranya kepemimpinan harus mempertimbangkan kebutuh-an semua pihak yang berkepen-tingan, seperti pelanggan, pemilik modal, pegawai, pemasok, pemodal, dan masyarakat; kepemimpinan harus membangun visi yang jelas tentang masa depan organisasi; kepemimpinan harus menetapkan tujuan dan target yang menantang; kepemimpinan harus menciptakan dan mempertahankan nilai-nilai bersama, keadilan dan model peran yang etis pada semua tingkat organisasi; kepemimpinan harus dapat membangun kepercayaan dan menghilangkan kecemasan setiap pegawainya; kepemimpinan harus memberikan kesempatan setiap pegawai untuk melakukan pelatihan sumber daya yang diperlukan, dan mereka bebas untuk bertindak dengan tanggung jawab dan akuntabilitas; dan kepemimpinan harus dapat menginspirasi, mendorong dan mengakui kontri-busi setiap pegawainya"

Sedangkan web resmi ISO, www.iso.org juga menyampaikan bahwa pemimpin pada berbagai level jabatan yang ada di dalam organisasi perlu mengarahkan kesatuan tujuan dan memperjelas arah organisasi. Hal tersebut diwujudkan dengan membangun semangat dan jiwa perjuangan yang tertuang dalam visi, strategi, kebijakan, sasaran, dan target yang perlu dicapai oleh seluruh komponen organisasi.

\section{Prinsip manajemen mutu ketiga : Keterlibatan Orang}

Penerapan prinsip melibat-kan orang atau keterlibatan orang di SD Katolik Santa Clara meliputi: 1) Rapat kerja yang diadakan pada akhir tahun pelajaran dan rapat koordinasi pada awal tahun pelajaran. Dalam rapat ini semua mitra kerja diundang untuk berpartisipasi dalam mengevaluasi dan memutuskan sesuatu. 2) Organisasi juga menyediakan kesempatan kepada mitra kerja untuk meningkatkan kompetensi sebagai pendidik maupun tenaga kependidikan melalui biasiswa studi S2. 3) Organisasi memberikan kesempatan kepada seluruh mitra kerja untuk mengikuti pelatihan yang diadakan pihak eksternal dengan sepengetahuan dan seijin kepala sekolah. 4) Sekolah mengatur sumber daya manusia dengan menerbitkan surat keputusan prosesn belajar mengajar. Dalam surat keputusan ini dituliskan siapa bekerja apa dengan siapa. 5) Sekolah juga memberikan penghar-gaan khusus bagi mitra kerja yang sudah mengabdi selama 25 tahun. Juga senada pendapat Gibson dalam Leovani (2016 : 246-247) yang mengartikan pelibatan pegawai berarti memampukan dan memberi Pelibatan karyawan (individual empowerment) adalah pemberian kesempatan dan 
dorongan kepada para karyawan untuk mendayagunakan bakat, ketram-pilanketrampilan, sumberdaya-sumberdaya, dan pengalaman-pengalaman mereka untuk menyelesaikan pekerjaan secara tepat waktu. Hasil-hasil yang dicapai dalam menerapkan konsep pemberdayaan di berbagai perusahaan adalah peningkatan efisiensi dan kualitas dalam produksi dan pelayanan.

Hal itu juga senada dengan teori (Fattah, 2008) yang mengemukakan upaya peningkatan mutu dan perluasan pendidikan membutuhkan sekurangkurangnya tiga faktor utama yaitu, (1) kecukupan sumber-sumber pendidikan dalam arti kualitas tenaga kependidikan, biaya dan sarana belajar, (2) mutu proses belajar mengajar yang mendorong siswa belajar efektif, dan (3) mutu keluaran dalam bentuk pengetahuan, sikap, keterampilan dan nilai-nilai. Dalam (Sagala, 2010) juga dikatan bahwa sekolah yang berhasil dalam meningkatkan mutu pendidikannya ditentukan oleh faktor-faktor antara lain: (1) Perumusan Visi, Misi dan Tujuan Sekolah (2) Evaluasi Diri Sekolah (3) Peranan kepala sekolah (4) Peningkatan Mutu Guru. Hal itu juga sejalan dengan standar ISO 9001:2015 klausul 7.1.1 sumber daya, Organisasi harus menetapkan dan menyediakan sumber daya yang dibutuhkan untuk pembentukan, implementasi, pemeliharaan dan peningkatan berkesinambungan dari sistem manajemen mutu. 7.1.2 Organisasi seharusnya menentukan dan menyediakan orang-orang yang diperlukan untuk operasi yang efektif dari sistem manajemen mutu dan untuk operasional dan pengendalian atas proses-proses yang ada.

\section{Prinsip manajemen mutu keempat : \\ Pendekatan Proses}

Penerapan prinsip manaje-men mutu keempat tentang Pendekatan proses yang terjadi di SD Katolik Santa Clara Surabaya meliputi: 1) Sekolah menentukan pedoman mutu peta proses. 2) Membuat perencanaan bersama dalam bentuk penyusunan sasaran mutu. Sasaran mutu disusun oleh setiap penanggungjawab bidang kerja, diperiksa oleh wakil manajemen dan disahkan oleh kepala sekolah atau pimpinan puncak. 3)
Menyusun rencana manajemen mutu. Dalam RMM ini dijabarkan proses atau langkah-langkah mencapai target sasaran mutu, sumber daya yang dibutuhkan, dokumen yang diperlukan, kapan dilakukan dan siapa penanggungjawabnya. 4) Perkembangan pencapaian sasaran mutu dimonitor dan dievaluasi setiap bulan. 5) Untuk memastikan bahwa apa yang direncanakan oleh organisasi melalui sasaran mutu tiap bidang kerja berjalan secara efektik dan efisien, maka diadakan audit internal setiap sementer. dan 6) Efektivitas kinerja system manajemen mutu ditinjau, diperbaiki dan ditingkatkan melalui Rapat Tinjauan Manajemen yang diadakan setiap semester sekali. Langkahlangkah yang diambil SD Katolik Santa Clara dalam menerapkan prinsip pendekatan proses juga sesuai dengan teori Deming dalam Fakhri: 2010 tentang pendekatan PDCA (plan - do - check act). Plan : mengidentifikasi dan menganalisis masalah. Do : mengembangkan dan menguji solusi yang berpotensi. Check : mengukur seberapa efektif pengujian solusi sebelumnya dan menganalisis apakah langkah tersebut dapat ditingkatkan. Act : mengimplementasikan solusi yang telah ditingkatkan secara menyeluruh.

Senada dengan Deming, juga memenuhi persyaratan dalam system manajemen mutu ISO 9001:2015. Perencanaan pada klausul 4, 5, 6 dan 7. Pelaksanaan pada klausul 8. Pemeriksaan pada klausul 9 dan Tindak lanjut klausul 10. Hasil penelitian ini juga menguatkan temuan penelitian Susilawati: 2013 dalam jurnal yang berjudul Implementasi Sistem Manajemen Mutu ISO 9001:2008 Di SMA Batik 1 Surakarta, yang menemukan bahwa Pelaksanaan SMM ISO 9001:2008 dengan menyusun sasaran mutu yang melibatkan 7 lini kerja yang ada di SMA Batik 1 Surakarta.

\section{Prinsip manajemen mutu kelima : \\ Peningkatan}

Pernyataan prinsip manaje-men mutu kelima: peningkat-an adalah Organisasi yang sukses memiliki fokus yang berkelanjutan pada perbaikan. Sekolah Dasar Katolik Santa Clara Surabaya dalam hal peningkatan telah melakukan hal-hal 
sebagai berikut: 1) Menindaklanjuti Laporan Ketidak-sesuaian Layanan (LKP). Semua temuan atau ketidaksesuaian yang ditemukan saat audit baik internal maupun eksternal ditindaklanjuti sampai tuntas dengan langkah-langkah: menemukan penyebabnya, melakukan koreksi, melakukan pencegahan, verifikasi dan validasi, menutup atau menyelesaikan proses penanganan LKP. 2) Mengadakan evaluasi melalui RTM dan menetapkan rekomendasi perbaikan dan peningkatan. 3) Menerapkan PDCA dalam menyusun RMM. 4) Mempunyai komitmen tertib administrasi dengan mengelola informasi terdokumentasi yang mudah telusur. Hal ini senada dengan teori (Nawawi, Hadari, \& Hartini, 1994) dalam manejemen fungsional pendekatan yang secara terus menerus difokuskan pada peningkatan kualitas, agar produknya sesuai dengan standar kualitas dari masyarakat yang dilayani dalam pelaksanaan tugas pelayanan umum (public service) dan pembangunan masyarakat (community development). Konsep-nya bertolak dari manajemen sebagai proses atau rangkaian kegiatan mengintegrasikan sumber daya yang dimiliki, yang harus diintegrasi pula dengan pentahapan pelaksanaan fungsifungsi manaje-men, agar terwujud kerja sebagai kegiatan memproduksi sesuai yang berkualitas. Setiap pekerjaan dalam manajemen mutu terpadu harus dilakukan melalui tahapan perencanaan, persiapan (termasuk bahan dan alat), pelaksanaan teknis dengan metode kerja/cara kerja yang efektif dan efisien, untuk menghasilkan produk berupa barang atau jasa yang bermanfaat bagi masyarakat.

Senada dengan pendapat di atas, (Zamroni, 2007) mengatakan bahwa peningkatan mutu sekolah adalah suatu proses yang sistematis yang terus menerus meningkatkan kualitas proses belajar mengajar dan faktor-faktor yang berkaitan dengan itu, dengan tujuan agar menjadi target sekolah dapat dicapai dengan lebih efektif dan efisien. Artinya peningkatan mutu pelayanan merupakan suatu usaha yang dilakukan terus menerus dan terencana. Apa yang diterapkan di SD Katolik Santa Clara berkaitan dengan prinsip peningkatan dalam menerapkan system manajemen mutu juga memenuhi prsyaratan SMM ISO 9001:2015 klausul 10.3: Peningkatan terus-menerus, Organisasi harus terus meningkat-kan kesesuaian, kecukupan, dan efektivitas sistem manajemen mutu. Organisasi harus mempertimbang-kan hasil dari analisis dan evaluasi dan output dari tinjauan manajemen, untuk menentukan apakah ada kebutuhan atau peluang yang harus ditangani sebagai bagian dari peningkatan terus-menerus.

\section{Prinsip manajemen mutu keenam : \\ Pengambilan Keputusan Berdasarkan Bukti \\ Berdasarkan temuan pene-litian,} dalam menerapkan prinsip manajemen mutu keenam, pengambilan keputusan berdasakan bukti, SD Katolik Santa Clara Surabaya mempertimbangkan: masukan dari mitra kerja, (2) hasil survey kepuasan pelanggan, (3) hasil audit, (4) hasil rapat dinas, (5) masukan dari yayasan, (6) Berdasarkan evaluasi dan laporan pertanggungjawaban, (7) hasil penilaian siswa. Hasil temuan ini sesuai dengan indikator keberhasil-an dalam meningkatkan mutu pendidikan (Sagala, 2010) khususnya indicator ke-10: "Sekolah melakukan evaluasi perbaikan yang berkelanjutan dan merupakan proses penyempurnaan dalam meningkatkan mutu keseluruhan, mencakup organisasi, tanggung jawab, prosedur dan sumber daya". Tindakan-tindakan yang dilakukan SD Katolik Santa Clara juga sesuai dengan persyaratan system manajemen mutu ISO 9001:2015. Klausul 9.1.3 Analisa dan evaluasi: Organisasi harus menganalisis dan mengevaluasi data dan informasi yang sesuai yang timbul dari pemantauan, pengukur-an. Hasil pengukuran harus diguna-kan untuk mengevaluasi: 1) kesesuaian produk dan layanan, 2) tingkat kepuasan pelanggan; 3) kinerja dan efektivitas sistem manajemen mutu; 4) apakah perencanaan telah dilaksanakan dengan efektif; 5) kinerja penyedia eksternal; 6) Kebutuhan untuk peningkatan dalam sistem manajemen mutu. Klausul 10.3 Peningkatan terus menerus. Organisasi harus mempertimbang-kan hasil dari analisis dan evaluasi dan output dari tinjauan manajemen, untuk menentukan apakah ada kebutuhan atau 
peluang yang harus ditangani sebagai bagian dari peningkatan terus-menerus"

Pengambilan keputusan yang dilakukan di SD Katolik Santa Clara juga mengacu dalam (Salusu, 1996) bahwa salah satu jenis pengambilan keputusan adalah pengambilan keputusan berdasarkan fakta. Pengambilan keputusan berdasarkan fakta adalah pengambilan keputusan yang didukung dengan berbagai fakta yang memadai. Kumpulan fakta yang dikelompokkan secara sistematis dinamakan data. Dengan demikian data harus dioleh terlebih dahulu menjadi informasi yang kemudian dijadikan dasar pengam-bilan keputusan.

7. Prinsip manajemen mutu ketujuh :

Manajemen Hubungan

Manajemen hubungan atau manajemen relasional, yang dijalankan di SD Katolik Santa Clara Surabaya adalah (1) memilih komite sekolah, (2) mengadakan pertemuaan dengan orangtua siswa, (3) mengadakan survey kepuasan pelanggan, (4) mengidentifikasi pihak-pihak yang berkepentingan atau interested parties.

$\mathrm{Hal}$ di atas sejalan dengan pendapat (Kotler \& Keller, 2007) mendefinisikan CRM (Customer Relationship Management) sebagai keseluruhan proses membangun dan memelihara hubungan pelanggan yang menguntungkan dengan memberikan nilai dan kepuasan pelanggan yang tinggi sehingga nantinya mampu meningkatkan loyalitas pelanggan dengan empat aktivitas yaitu: Mengidentifikasi (identify), Mengakuisisi (acquire), Mempertahankan (retain), Mengembangkan (develop) dan, tentang Customer Relationship Management (CRM) yakni suatu strategi dan gaya manajemen untuk membangun dan memelihara hubungan dengan pelanggan yang menguntungkan dengan memperlihatkan nilai dan kepuasan pelanggan.

Prinsip manajemen relasional menjelaskan bahwa untuk mencapai kesuksesan yang berkelanjutan, organisasi harus mengelola hubungan dengan berbagai pihak yang berkepenting-an. Dalam manajemen mutu dijelaskan bahwa pihak yang berkentingan adalah orang atau kelompok yang memiliki kepentingan dalam keberhasilan atau kinerja organisasi. Dengan demikian, pihak-pihak yang berkepentingan dapat diartikan sebagai para pemangku kepentingan (stakeholders). Dengan kata lain, pihak yang berkepentingan dapat berasal dari dalam organisasi atau luar organisasi, seperti para pegawai, pelanggan, pemasok, pemilik modal, serikat pekerja, pemerintah, masyarakat. Dalam manajemen mutu dijelaskan bahwa organisasi perlu menjaga hubungan yang baik dengan pihak-pihak yang berkepentingan karena pihak-pihak tersebut dapat mempengaruhi kinerja organisasi. Lebih lanjut, kesuksesan organisasi secara berkelanjutan akan lebih mungkin dicapai ketika organisasi tersebut dapat mengelola hubungan dengan pihak yang berkepentingan, sehingga organisasi dapat mengoptimalkan dampaknya terhadap kinerja organisasi. Lebih spesifik, prinsip manajemen relasional menekankan pentingnya organisasi untuk melakukan kerjasama yang saling menguntung-kan, sehingga tidak ada pihak yang dirugikan; menetapkan pengem-bangan dan perbaikan kegiatan bersama; menginspirasi, mendo-rong, dan mengakui prestasi yang dicapai pemasok; melakukan komunikasi secara jelas dan terbuka dengan para pemegang saham; mengidentifikasi dan memilih pemasok kunci; menetapkan hubungan dengan menyeimbangkan keuntungan jangka pendek dengan pertimbangan jangka panjang.

Temuan penelitian di atas juga sejalan dengan teori George C. Edward tentang implementasi kebijakan dalam (Fryde, 2018) khususnya variable pertama: "Komunikasi, yaitu keberhasilan implementasi kebijakan mensyaratkan agar implementor mengetahui apa yang harus dilakukan, dimana yang menjadi tujuan dan sasaran kebijakan harus ditransmisikan kepada kelompok sasaran, sehingga akan mengurangi distorsi implementasi". Senada dengan itu (Nawawi et al., 1994) mengatakan : "Manajemen mutu terpadu adalah manajemen fungsional dengan pendekatan yang secara terus menerus difokuskan pada peningkatan kualitas, agar produknya sesuai dengan standar kualitas dari 
masyarakat yang dilayani dalam pelaksanaan tugas pelayanan umum dan pembangunan masyarakat". Sementara antara masyarakat dengan sekolah sebagai berikut: 1) mengembangkan pemahaman kepa-da masyarakat tentang maksud dan sasaran dari sekolah, 2) memberikan penilaian program kepada masyarakat untuk memenuhi kebutuhan sekolah, 3) menjalin dan meningkatkan hubungan harmonis antara orang tua siswa dengan guru-guru dalam memenuhi kebutuhan anak didik, 4) membangun kesan positif dan memelihara kepercayaan tentang sekolah, 5) menginformasi-kan kepada masyarakat tentang rencana program dan kegiatan sekolah, 6) mencari bantuan dan dukungan bagi pemeliharaan dan peningkatan program sekolah, 7) sekolah sebagai jasa lembaga pendidikan memberikan pelayanan yang memuaskan kepada pelanggan (siswa, keluarga dan masyarakat lain), 8) supaya kreativitas mencari dana pendidikan alternatif dalam bentuk kerjasama dengan lembaga lain.

Hasil penelitian di atas juga sesuai dengan standar system manajemen mutu ISO 9001:2015. Klausul 4.1 Memahami organisasi dan konteksnya: Organisasi harus menentukan isu-isu eksternal dan internal yang relevan dengan tujuan dan arah strategis, organisasi dan yang mempengaruhi kemampuan-nya untuk mencapai hasil yang diinginkan dari system manajemen mutunya. Klausul 4.2 Memahami kebutuhan dan harapan dari pihak-pihak yang berkepentingan. Organisasi harus memantau dan meninjau informasi tentang pihak-pihak yang berkepentingan dan persyaratan yang relevan dengan mereka

\section{Faktor pendukung implementasi SMM ISO 9001:2015}

Dalam paparan hasil penelitian disampaikan bahwa faktor pendukung implementasi SMM ISO 9001:2015 adalah mempunyai kecukupan sumber daya manusia, sistem kerja yang baik, mempunyai sumber daya manusia yang kompeten dan mempunyai motivasi kerja yang tinggi, ketersediaan sarana prasarana yang memadai, kepemimpinan komunikatif. Hal ini sejalan dengan teori George C. Edward tentang implementasi kebijakan pendidikan yang mengatakan bahwa implementasi kebijakan dipengaruhi oleh empat variabel, yaitu komunikasi, sumberdaya, disposisi dan struktur birokrasi. Sementara itu faktor pendukung pencapaian kinerja adalah kemampuan (ability) dan faktor motivasi (motivation). Keberhasilan kinerja dipengaruhi oleh 5 faktor: 1) Personal factor: ditunjukkan tingkat keterampilan, kompetensi yang dimiliki, motivasi dan komitmen individu, 2) Leadership factors: ditentukan kualitas dorongan bimbingan, dan dukungan yang dilakukan manajer dan team leader, 3) Team factors: ditunjukkan kualitas dukungan yang diberikan oleh rekan sekerja, 4) System Factors: ditunjukkan adanya system kerja dan fasilitas yang diberikan organisasi, dan 5) Contextual/Situational Factors: ditunjukkan tingginya tingkat tekanan lingkungan internal dan eksternal.

\section{Faktor penghambat implementasi SMM ISO 9001:2015}

Dalam paparan hasil penelitian disampaikan bahwa faktor penghambat implementasi SMM ISO 9001:2015 adalah sumber daya manusia yang tidak mau maju, pemahaman klausul ISO 9001:2015 yang belum merata diantara para pemegang prosedur dan kesulitan membagi waktu. Pemahaman standar ISO 9001:2015 belum dipahami oleh semua mitra kerja.

Beberapa faktor yang mempengaruhi kinerja menurut Kasmir (2016) adalah 1) kemampuan dan keahlian, 2) pengetahuan, 3) rencana kerja, 4) kepribadian, 5) motivasi kerja, 6) kepemimpinan, 7) gaya kepemimpinan, 8) budaya organisasi, 9) kepuasan kerja, 10) lingkungan kerja, 11) loyalitas, 12) komintmen dan 13) disiplin kerja. Tentang kepribadian dijelaskan bahwa setiap orang mempunyai karakter yang berbeda-beda antara yang satu dan yang lainnya. Ada yang mempunyai karakter baik dan mendukung efektivitas kinrja namun ada juga karyawan atau pegawai yang mempunyai karakter kurang atau tidak baik yang bisa menghambat pencapaian tujuan bersama. 


\section{KESIMPULAN}

1. Fokus pelanggan

SD Katolik Santa Clara Surabaya sudah menerapkan prinsip focus pelanggan dalam implement-tasi Sistem Manajemen Mutu ISO 9001:2015. Hal ini tampak dari tindakan yang diambil dalam penerapannya yaitu dengan mengidentifikasi pihak-pihak terkait, mengadakan survey kepuasan pe-langgan dan menindaklanjuti hasil-nya.

2. Kepemimpinan

Pimpinan puncak atau kepala sekolah telah menjalankan tugasnya sebagai penanggungjawab utama penerapan system Mane-jemen mutu ISO 9001:2015 dengan cara berperan aktif dalam berbagai kegiatan mulai dari perencanaan, pelaksanaan, evaluasi dan tindak lanjut, namun dalam hal pemberian hadiah atau reward bagi mitra kerja yang telah menjalankan tugasnya dengan baik sebagai bentuk pengakuan kontribusinya tidak ditemukan dokumennya.

3. Pelibatan orang

Sekolah telah melibatkan semua mitra kerja dengan cara setiap awal tahun mengadakan pembagian tugas, sosialisasi visi, misi dan kebijakan mutu serta sasaran mutu dari tiap-tiap pemegang prosedur

\section{Pendekatan proses}

Untuk menjaga konsistensi, efektif dan efisien penerapan system manajemen mutu ISO 9001;2015, dapat disimpulkan bahwa sekolah telah menentukan peta proses, memahami konteks organisasi dengan membuat analisa SWOT, menganalisa risiko, menyusun sasaran mutu, mengevaluasi dan menindaklanjuti dengan baik.

\section{Perbaikan}

Sekolah telah melakukan perbaikan dengan cara memperbaiki ketidaksesuain atau menindaklanjuti temuan audit, membuat dan membuat rekomendasi perbaikan setelah mengadakan Rapat Tinjauan Manajemen

6. Pengambilan berdasarkan bukti

Hasil audit internal, hasil pengukuran sasaran mutu dan hasil survey kepuasan pelanggan dijadikan landasan dalam pengambilan keputusan atau dasar penyusunan rencana kegiatan.

7. Manajemen hubungan
Sekolah mengadakan pertemuan orangtua siswa setiap awal tahun pelajaran untuk mensosialisasikan rencana kegiatan sekolah dan menampung masukan dari orangtua siswa. Selain itu sekolah juga melibatkan orangtua dalam program : orangtua mengajar

\section{SARAN}

Berdasarkan hasil penelitian peneliti memberikan saran sebagai berikut:

1. Interested parties dianalisis dan dipetakan dengan pendekatan kepentingan dan pengaruh yang dimiliki oleh setiap pihak yang berkepentingan sehingga tergambar kepentingan dan pengaruh dari setiap pelanggan.

2. Dibuat ketentuan dalam pemberian hadiah kepada mitra kerja sebagai bentuk pengakuan kontribusi terhadap sehingga dapat memacu dalam melibatkan diri. Sebaiknya sekolah mempunyai program inovasi, karena dalam penelitian peneliti tidak menemukan program inovasi sebagai bentuk melebihi harapan pelanggan

\section{DAFTAR RUJUKAN}

Cepi, T. (2015). Pengembangan Manajemen Sekolah. Bandung: Rosdakarya.

Crawford, L. E. D., \& Shutler, P. (1999). Total quality management in education : problems and issues for the classroom teacher. The International Journal Fo Educational Management, 13(2), 67-72.

Farkhondehzadeh, A., Reza, M., Karim, R., Roshanfekr, M., Azizi, J., \& Hatami, F. L. (2013). Total Quality Management ( TQM ) in Iranian primary schools teachers. 2(3), 634-640.

Farooq, M. S., Akhtar, M. S., Ullah, S. Z., \& Memon, R. A. (2007). APPLICATION OF TOTAL QUALITY MANAGEMENT IN EDUCATION. III, 1-11.

Fattah, N. (2008). Landasan Manajemen Pendidikan. Bandung: Rosdakarya.

Fryde, E. B. (2018). Financial Resources of 
Edward III in the Netherlands, 133740 (2nd part ). 40, 1142-1216.

Hanief, S. G. (2017). Arsitektur Mutu Pendidikan Indonesia. Jakarta: Bumi Aksara.

Hasan, K., Islam, S., Shams, A. T., \& Gupta, H. (2018). Total Quality Management ( TQM ): Implementation in Primary Education System of Bangladesh. 7(3), 370-380. https://doi.org/10.22105/riej.2018.128 170.1041

Karakus, M. (2015). Total quality management practices in Turkish primary schools Quality Assurance in Education Emerald Article: Total quality management practices in Turkish primary schools. (January 2009).

https://doi.org/10.1108/096848809109 29917

Kotler, P., \& Keller. (2007). Manajemen Pemasaran. Jakarta: Indeks.

Mukolwe, O., Michael, O., \& Jack, O. (2017). IMPLEMENTATION OF TOTAL QUALITY MANAGEMENT IN PRIMARY SCHOOLS AS A PANACEA FOR LOW ACADEMIC. 5(5), 54-63.

Nawawi, Hadari, \& Hartini, M. (1994). Kebijakan Pendidikan Di Indonesia Ditinjau Dari Sudut Hukum. Yogyakarta: Gajah Madha Univesity Press.

Pourrajab, M. (2015). Applying Total Quality Management in the Classroom and Solving Students Failure. (February).

Ruslan, R. (2010). Manajemen Public Relation and Media. Jakarta: Rajawali Press.

Sagala, S. (2010). manajemen strategik dalam peningkatan mutu pendidikan. BAndung: Rosdakarya.

Salusu, J. (1996). Pengambilan Keputusan Stratejik Untuk Organisasi Publik dan Organisasi Non Profit. Jakarta: Grasindo.

Satori, D. (2016). Pengawasan dan Penjaminan Mutu Pendidikan.
Bandung: Alfabeta.

Sohel-uz-zaman, A. S., \& Anjalin, U. (2016). Implementing Total Quality Management in Education :

Compatibility and Challenges. 207217.

https://doi.org/10.4236/jss.2016.41101 7

Sugiyono. (2012). Metode Penelitian Kuantitatif Kualitatifdan $R \& D$. Bandung: Alfabeta.

Taahyadin, F., \& Daud, Y. (2018). Total Quality Management in School. 20(6), 7-13. https://doi.org/10.9790/487X2006010713

Yau, H. K., Lai, A., \& Cheng, F. (2013). Quality Management in Primary Schools. 1(4), 16-31.

Zamroni. (2007). Meningkatkan Mutu Sekolah. Jakarta: PASP Muhammadiyah. 